\title{
Chemical profiles and antioxidant properties of Bruguiera gymnorrhiza fruit extracts from Central Sulawesi, Indonesia
}

\author{
${ }^{1, *}$ Riyadi, P.H., ${ }^{2}$ Tanod, W.A., ${ }^{3}$ Dewanto, D.K., ${ }^{4}$ Herawati, V.E., ${ }^{1}$ Susanto, E. and \\ ${ }^{5}$ Aisiah, $\mathrm{S}$. \\ ${ }^{1}$ Department of Fish Product Technology, Faculty of Fisheries and Marine Science, Universitas \\ Diponegoro, Semarang, Central Java 50275 Indonesia \\ ${ }^{2}$ Department of Fisheries and Marine, Politeknik Negeri Nusa Utara, Tahuna, North Sulawesi 95812 \\ Indonesia \\ ${ }^{3}$ Department of Fishing Technology, Sekolah Tinggi Perikanan dan Kelautan, Palu, Central Sulawesi 94118 \\ Indonesia \\ ${ }^{4}$ Department of Aquaculture, Faculty of Fisheries and Marine Science, Universitas Diponegoro, Semarang, \\ Central Java 50275 Indonesia \\ ${ }^{5}$ Study Program of Aquaculture, Faculty of Fisheries and Marine, Universitas Lambung Mangkurat, \\ Banjarbaru, South Kalimantan 70714, Indonesia
}

\section{Article history: \\ Received: 9 February 2021 Received in revised form: 21 March 2021 \\ Accepted: 24 March 2021 Available Online: 28 July 2021}

Keywords: ADMET, Antioxidant, Bruguiera gymnorrhiza, GCMS,

Nutraceutical

DOI:

https://doi.org/10.26656/fr.2017.5(S3).007

\begin{abstract}
Bruguiera gymnorrhiza is one of the mangrove species that a source of antioxidants. Antioxidant substances are able to protect cells from oxidative stress and other related diseases. This study aimed to evaluate the chemical profiles, predicted biological activity, and antioxidant activity of the B. gymnoriza fruit extracts. The research methods included sampling, extraction (maceration with $\mathrm{MeOH}: \mathrm{DCM}$ ), identification of chemical profiles (GCMS spectra analysis), assaying for computational analysis (PASS server and ADMET), antioxidants (DPPH radical scavenging), and total phenolic content (FolinCiocalteu). Bruguiera gymnorrhiza fruits was collected from Central Sulawesi, Indonesia. The chemical profiles detected in the $B$. gymnorrhiza fruit extracts, namely isopimaradiene $(64.20 \%)$; 4-(2-Aminopropyl) phenol (19.06\%); dimethylaminodimethylphosphene oxide (9.40\%); 3-amino-2-benzylbutanoic acid (5.46\%); and 1,4dideuteriooctane (1.89\%). PASS server analysis showed that the five compounds detected from B. gymnorrhiza fruit have the potential as an NF-E2-related factor (Nrf2) stimulant and oxygen scavenger. The ADMET analysis results indicated that B. gymnorrhiza fruits could be developed as folk medicine and nutraceutical products.
\end{abstract}

\section{Introduction}

Mangroves are a forested ecosystem widely distributed in tropical and subtropical areas (Zhu et al., 2012; Al-Maqtari and Nagi, 2014; Suh et al., 2014). Indonesia is recognized as a centre for biodiversity globally as an archipelago country due to its rich natural habitats, including mangroves (Kusmana, 2014). About $23 \%$ of total world mangrove forests are located in Indonesia (Armitage, 2020), with 202 mangroves species, e.g., Avicennia sp., Bruguiera sp., Rhizophora sp., and Xylocarpus sp. (Noor et al., 2006; Kusmana, 2014). They have been utilized for several purposes, such as wood for house constructions, charcoal (Dahdouh-Guebas et al., 2000), food ingredients (Jariyah et al., 2014; Analuddin et al., 2019; Amin et al., 2021), complementary foods (Kardiman et al., 2017), food products (Situmorang and Barus, 2015; Wibawanti et al., 2018), and folk medicine (Rout and Basak, 2014; Suh et al., 2014).

Mangroves have long been used as folk medicine and therapeutics for diarrhoea, indigestion, and inflammation in coastal communities (Rout and Basak, 2014; Suh et al., 2014). Their efficacies are related to the level and composition of bioactive compounds. It is expected to have several physiological activities such as anti-fungal (Acharya et al., 2020), anti-bacteria (Behbahani et al., 2018; Eswaraiah et al., 2020), antioxidants (Arulkumar et al., 2020; Karim et al., 2020), and anti-hemolytic (Karim et al., 2020). 
The coast of Central Sulawesi, Indonesia, is the home of various mangrove species such as Rhizophora mucronata, Sonneratia alba, Avicennia marina, and Bruguiera gymnorrhiza (Damanik and Djamaludin, 2012; Lisna et al., 2017; Dewanto et al., 2018; Alhaffaf et al., 2019). B. gymnorrhiza, belonging to Rhizophoraceae, is reported as an essential and major mangrove species in the Asia Pacific, including Central Sulawesi (Zhu et al., 2012; Kusmana, 2014). It is traditionally used as a medicinal plant (Lin et al., 2020). The previous study has revealed that methanol leaves extract of B. gymnorrhiza and Heritiera littoralis revealed free radical scavenging, anti-haemolytic, cytotoxic, and antibacterial activity (Karim et al., 2020). Meanwhile, the aqueous extract of $B$. gymnorrhiza exhibited a protective effect against dextran sulfate sodium (DSS)-induced ulcerative colitis (Chen et al., 2020). In addition, the B. gymnorrhiza roots extract has been reported to inhibit the Escherichia coli, Staphylococcus aureus, and urinary tract infections (UTI) bacterial pathogens, e.g., Pseudomonas aeruginosa growth (Acharya et al., 2020). However, explorations of B. gymnorrhiza fruits have been limited. Even though $B$. gymnorrhiza fruits have reported possessed biological activities, it is therefore related to the chemical profiles and their antioxidant activities.

Therefore, in this study, we reported B. gymnorrhiza fruit extract's chemical profiles with GCMS, the prediction of biological activity with PASS server and ADMET analysis, and antioxidant activity with DPPH radical scavenging and total phenol content with FolinCiocalteu.

\section{Materials and methods}

\subsection{Sampling location}

Bruguiera gymnorrhiza fruits were collected from the coastal area of Tomini Bay in Laemanta, Parigi Moutong, Central Sulawesi, Indonesia $(-0.1847 \mathrm{~S}$ and 120.0088 E) (Figure 1) in April 2020. Mangrove fruits were randomly taken from a mangrove tree $B$. gymnorrhiza followed by identification based on Noor et al. (2006). After collection, the B. gymnorrhiza fruits were washed with water to eliminate the presence of contaminants.

\subsection{Materials}

Free radical 2,2-Diphenyl-1-Picrylhydrazyl (DPPH, Merck-1898664), distilled water, dichloromethane (DCM, $\mathrm{CH}_{2} \mathrm{Cl}_{2}$; (Merck- 106050), methanol (MeOH, $\mathrm{CH}_{3} \mathrm{OH}$; Merck- 107018), Folin-Ciocalteu reagent (Merck-109001), gallic acid $\left(\mathrm{C}_{6} \mathrm{H}_{2}(\mathrm{OH})_{3} \mathrm{CO}_{2} \mathrm{H}\right.$, Merck842649 ; purity $\geq 98 \%), \mathrm{Na}_{2} \mathrm{CO}_{3}$ were purchased from CV Amani Media Malang and CV Intraco Makassar,
Indonesia.

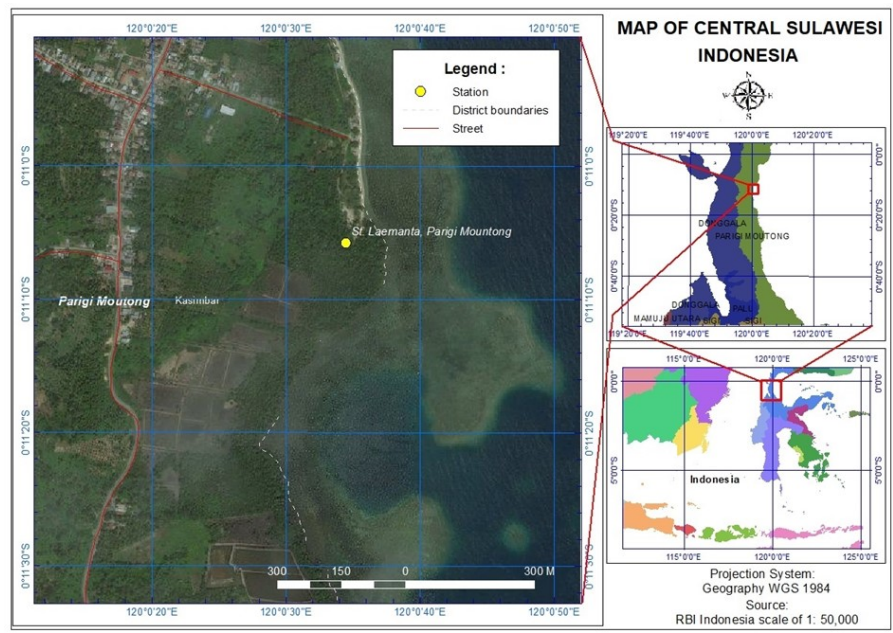

Figure 1. Sample coordinates for Bruguiera gymnorrhiza from Laemanta, Central Sulawesi, Indonesia

\subsection{Preparation of Bruguiera gymnorrhiza extracts}

Before extractions, $500 \mathrm{~g}$ of B. gymnorrhiza fruits were dried at $50-60^{\circ} \mathrm{C}$ using an oven (Finco OV50) for 15-20 hrs. After drying, the samples were pounded into flour. The crude extract of B. gymnorrhiza (100 g) was obtained by extraction with the combination of $\mathrm{MeOH}$ and DCM (1: 1) for 48 hrs (Hsiao et al., 2015; Putra et al., 2016). The filtrate obtained by the extraction was filtered with filter paper (Whatman No. 42). The filtrate was vacuum-concentrated at $40-45^{\circ} \mathrm{C}$ using a rotary evaporator (EYELA N-1100) to obtain the crude extracts. The extraction process was carried out three times. Then, the extracts were weighed and dissolved in $30 \% \mathrm{MeOH}$ then stored at $4-5^{\circ} \mathrm{C}$ for further analysis.

\subsection{Chemical profiles screening using GCMS}

The chemical components of $B$. gymnorrhiza fruits extract were profiled using Gas Chromatography-Mass Spectrometry (GCMS). The analysis was performed on an HP 6890 GCMS system (Hewlett-Packard, California, USA) equipped with a capillary column (Agilent 19091S $-433 \mathrm{HP}-5 \mathrm{MS}$; $30 \mathrm{~m} \times 250 \mu \mathrm{m}$ i.d.; Santa-Clara, California, USA). The carrier gas was helium at a flow rate of $1 \mathrm{~mL} / \mathrm{min}$. The oven temperature was set at $325^{\circ}$ C. The pre-oven temperature was $150^{\circ} \mathrm{C}$ held at $2^{\circ} \mathrm{C} /$ min. It ran for $10^{\circ} \mathrm{C} / \mathrm{min}$ and was then increased to $240^{\circ}$ $\mathrm{C}$, holding time for 11 mins. The total running time was 24 mins. The scanning range was 50 - 550 amu. Structural assignments were based on analysis of mass spectral fragmentation patterns and compared with mass spectra in the National Institute of Standards and Technology (NIST) and Wiley's compound profile database (Tanod et al., 2019).

\subsection{Prediction of biological activity}

The chemical profiles from B. gymnorrhiza fruits extract by GCMS were predicted through Prediction of 
Activity Spectra for Substances (PASS)-way2Drug server (http://www.pharmaexpert.ru/passonline/ index.php). PASS server is used to predict the chemical compounds' biological activity (Aisiah et al., 2020; Riyadi, Romadhon, Anggo et al., 2020). The structural target compounds obtained from the National Centre for Biotechnology Information (https:// pubchem.ncbi.nlm.nih.gov/) in the form of canonical SMILE were used to predict their biological activity. The chemicals profile structure was also used to estimate their ADMET (absorption, distribution, metabolism, excretion, and toxicity) through AdmetSAR (http:// lmmd.ecust.edu.cn/admetsar2).

\subsection{Determination of total phenol contents}

Total phenolic content (TPC) of B. gymnorrhiza fruits extract was determined by the Folin-Ciocalteu (FC) reagent method (Blainski et al., 2013 and LamuelaRaventós, 2017). The gallic acids $(1 \mathrm{mg} / \mathrm{mL})$ were used as a standard by diluting ethanol: distilled water (1: 1). Gallic acid solutions were diluted in serial dilution with concentrations 5, 20, 40, 60, 80, and $100 \mu \mathrm{g} / \mathrm{mL}$. From each dilution concentration, $1 \mathrm{~mL}$ of gallic acid was taken, and $9 \mathrm{~mL}$ of distilled water was added. Then those aliquots were mixed with $1 \mathrm{~mL}$ of $\mathrm{FC}$ reagent (homogenization) and incubated for $8 \mathrm{mins}$ at room temperature. After incubation, $3 \mathrm{~mL}$ of $20 \% \mathrm{Na}_{2} \mathrm{CO}_{3}$ was added, and the mixture was allowed to stand at room temperature for $2 \mathrm{hrs}$. The absorbance was measured at $750 \mathrm{~nm}$. The standard curve for gallic acid was prepared with gallic acid concentration $(\mu \mathrm{g} / \mathrm{mL})$ with an absorbance value.

The aliquot $(1 \mathrm{mg} / \mathrm{mL}$ extract $)$ was added with 10 $\mathrm{mL}$ of distilled water $+1 \mathrm{~mL}$ of $\mathrm{FC}$ reagent and incubated as described above. Then TPC content was measured at $750 \mathrm{~nm}$. B. gymnorrhiza fruits extract's total phenolic content was then calculated based on a gallic acid standard curve and expressed as $\mathrm{mg}$ of gallic acids equivalent (GAE)/g extract.

\subsection{DPPH radical scavenging activity}

DPPH is a free radical, stable at room temperature, which produces a violet solution in ethanol. Antioxidants' presence will reduce the colour and change into uncoloured ethanol solution (Clarke et al., 2013). The total free radical scavenging capacity of Free radical scavenging capacity was assessed according to the previously reported method using a stable DPPH (Molyneux, 2004; Dewanto et al., 2019). The extract was expressed as the $\mathrm{IC}_{50}$, which is the antioxidant concentration required to quench $50 \%$ of the initial DPPH under the experiment treatment. Vitamin E, known as the strong DPPH radical scavenger ( $\mathrm{Yu}$ et al.,
2002), was used as the positive control. The $\mathrm{IC}_{50}$ value was converted to the vitamin $\mathrm{E}$ equivalent. Each evaluation was performed in triplicate.

Bruguiera gymnorrhiza fruit extracts $(200 \mu \mathrm{g} / \mathrm{mL})$ in ethanol solution was prepared and diluted into several concentrations $(20,40,60,80,100 \mu \mathrm{g} / \mathrm{mL}) .2 \mathrm{~mL}$ aliquot of each concentration was reacted with $50 \mu \mathrm{M}$ DPPH ethanol solution. The mixtures were homogenized and stand for 30 mins in the dark at room temperature before reading against a blank at $517 \mathrm{~nm}$ (UV-VIS spectrophotometer T90 + PG Instruments Ltd).

The DPPH radical scavenging effect in percentage (\%) was calculated according to the following equation:

$$
\text { DPPH Scavenging Effect }(\%)=\frac{A_{\text {blank }}-A_{\text {sample }}}{A_{\text {blank }}} \times 100 \%
$$

Where $A_{\text {sample }}$ is the absorbance of a sample solution and $A_{\text {blank }}$ is the absorbance of the blank solution (containing all reagents except the test sample).

The half of maximum concentration in reducing initial DPPH was calculated from the graph by plotting inhibition concentrations against initial DPPH to obtain a linear regression equation, $y=a+b x$. Each measurement was carried out in triplicates.

\section{Results}

\subsection{Sample identification}

Identification was carried out according to Noor et al. (2006). The samples included in the B. gymnorrhiza based on the leaves' shape and tip, the types of roots, fruit, and flowers. BG's bark has lenticels, and the surface is smooth to rough, dark gray to brown. BG roots are like planks extending to the side at the tree's base and developing several knee roots. Characteristics of BG leaves are skinned green on top and yellow on bottom. The BG leaves shape is elliptical to elliptical-lanceolate and had average length and width 4.5 to $7 \mathrm{~cm}$ and 8.5 to $22 \mathrm{~cm}$, respectively. Characteristics of BG fruit are straight, blunt, and dark green-purple when fresh with length $(12-30 \mathrm{~cm})$ and diameter $(1.5-2 \mathrm{~cm})$ (Figure 2).

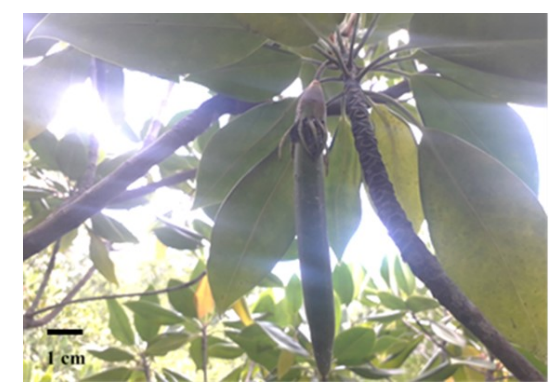

Figure 2. Bruguiera gymnorrhiza mangrove fruits from Laemanta, Central Sulawesi, Indonesia 
3.2 Chemical profiles of Bruguiera gymnorrhiza fruit extracts

The GCMS analysis showed the presence of 5 compounds from B. gymnorrhiza fruit extracts (Table 1). The chemical profiles were identified through mass spectrometry attached with GC. The total ion chromatogram (TIC) of the GCMS analysis confirms that five compounds and their different retention time $(4,700$ to 22,824 mins) are presented in Figure 3. The chemical profiles contained in B. gymnorrhiza fruits extracts are isopimaradiene (64.20\%), 4-(2Aminopropyl) phenol (19.06\%), dimethylaminodimethylphosphene oxide $\quad(9.40 \%)$, 3-amino-2benzylbutanoic acid (5.40), and 1,4-dideuteriooctane $(1.89 \%)$.

Abundance

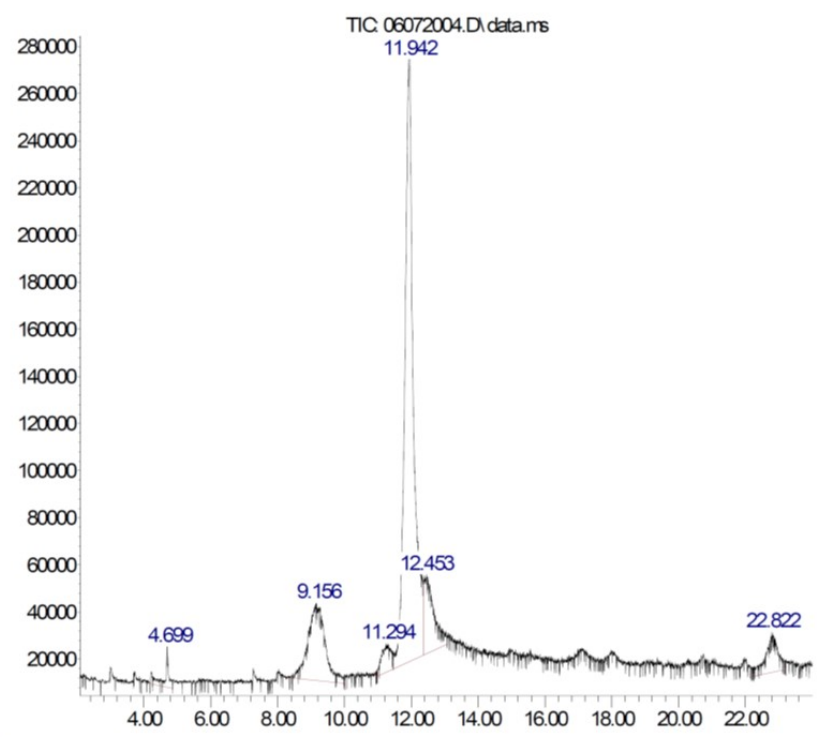
Time $\rightarrow$

Figure 3. GCMS chromatogram of mangrove fruit extracts Bruguiera gymnorrhiza

\subsection{Biological activity prediction of fruits extracts}

The prediction of biological activity was performed with chemical profiles in B. gymnorrhiza fruits extracts and presented in Table 2. The biological activity prediction was used the PASS server. The PASS server could predict compounds' biological activity based on their formula with $95 \%$ accuracy (Filimonov and Poroikov, 2008; Riyadi, Tanod, Wahyudi et al., 2020).
The biological activity prediction value of the $B$. gymnorrhiza fruits extracts' chemical profiles was expressed as a "probability to be active" (Pa). The chemical profiles are probable to act as antioxidants, free radical scavengers, oxygen scavengers, and NF-E2related factor (Nrf2) stimulant properties (Figure 4). The PASS server was analysed and dominated by Nrf2 stimulant and oxygen scavenger, which play a role in protecting oxidative stress.

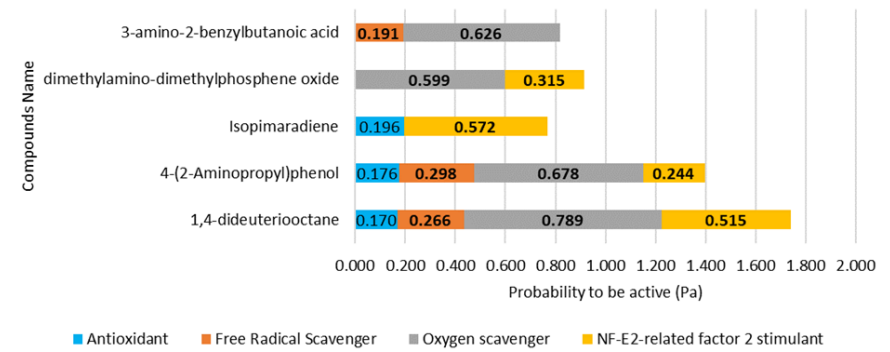

Figure 4. Probability to be active from Bruguiera gymnorrhiza fruit extracts profiles with PASS Server

ADMET analysis is an important parameter to determine whether a natural product will reach the body's target when administered orally (Dong et al., 2018; Natesh et al., 2021). The ADMET properties of compounds are important to the development process of nutraceutical and pharmaceutical products (van de Waterbeemd and Gifford, 2003; Guan et al., 2019). The utilization of $B$. gymnorrhiza fruits extracts for human health benefits needs to be satisfied with the ADMET properties before further applications. Therefore, we evaluated the ADMET properties of B. gymnorrhiza fruits extracts chemical profiles by using admetSAR (Table 2).

The chemical profiles of $B$. gymnorrhiza fruit extracts showed good human intestinal absorption. However, only dimethylamino-dimethyl phosphene oxide did not show well on the caco-2 permeability (Table 2). Interestingly, none of the selected chemical profile functions is acted as both P-glycoprotein (P-gp) substrate and inhibitor. Furthermore, 4-(2-Aminopropyl) phenol), isopimaradiene, and 3-amino-2-benzyl butanoic acid from the $B$. gymnorrhiza fruits extracts act as substrate of CYP450 2D6, CYP450 3A4, and CYP450 $2 \mathrm{C} 9$, respectively. In contrast, none of the chemical profiles acts as inhibitors of CYP450 enzymes, which

Table 1. Chemical profiles of Bruguiera gymnorrhiza fruit extracts by GCMS

\begin{tabular}{clcccc}
\hline RT (Min) & \multicolumn{1}{c}{ Chemical Profiles } & Formula & $\begin{array}{c}\text { Molecular Weight } \\
(\mathrm{g} / \mathrm{mol})\end{array}$ & Area (\%) & Pubchem CID \\
\hline 4.700 & 1,4-dideuteriooctane & $\mathrm{C}_{8} \mathrm{H}_{18}$ & 116.24 & 1.89 & 151945284 \\
9.158 & 4-(2-Aminopropyl)phenol & $\mathrm{C}_{9} \mathrm{H}_{13} \mathrm{NO}$ & 151.21 & 15.93 & 3651 \\
11.295 & & & & 3.13 & 13969536 \\
11.940 & Isopimaradiene & $\mathrm{C}_{20} \mathrm{H}_{32}$ & 272.5 & 64.2 & 521290 \\
12.453 & dimethylamino-dimethylphosphene oxide & $\mathrm{C}_{4} \mathrm{H}_{12} \mathrm{NOP}$ & 121.12 & 9.4 & 541835 \\
22.824 & 3-amino-2-benzylbutanoic acid & $\mathrm{C}_{11} \mathrm{H}_{15} \mathrm{NO}_{2}$ & 193.24 & 5.46 & 5 \\
\hline
\end{tabular}


Table 2. Admet profile of Bruguiera gymnorrhiza fruit extracts

\begin{tabular}{|c|c|c|c|c|c|}
\hline ADMET Profile & $\begin{array}{l}\text { 1,4-dideuterio } \\
\text { Octane }\end{array}$ & $\begin{array}{c}4-(2- \\
\text { Aminopropyl) } \\
\text { phenol) }\end{array}$ & Isopimara-diene & $\begin{array}{c}\text { dimethylamino- } \\
\text { pdimethyl } \\
\text { phosphene oxide }\end{array}$ & $\begin{array}{c}\text { 3-amino-2- } \\
\text { benzyl butanoic } \\
\text { acid }\end{array}$ \\
\hline \multicolumn{6}{|l|}{ Absorption properties } \\
\hline Human Oral Bioavailability & $+(0.5286)$ & $-(0.5857)$ & $+(0.6571)$ & $+(0.6000)$ & $+(0.8286)$ \\
\hline Human Intestinal Absorption & $+(0.8865)$ & $+(0.9861)$ & $+(0.9828)$ & $+(0.8805)$ & $+(0.9945)$ \\
\hline Caco-2 Permeability & $+(0.9825)$ & $+(0.9499)$ & $+(0.8457)$ & $-(0.5244)$ & $+(0.5957)$ \\
\hline P-glycoprotein Substrate & $-(0.9516)$ & $-(0.8011)$ & $-(0.9000)$ & $-(0.98)$ & $-(0.9485)$ \\
\hline P-glycoprotein Inhibitor & $-(0.9850)$ & $-(0.9903)$ & $-(0.8387)$ & $-(0.988)$ & $-(0.9903)$ \\
\hline \multicolumn{6}{|l|}{ Distribution properties } \\
\hline Blood-Brain Barrier (BBB) B & $+(1.000)$ & $-(0.993)$ & & $+(0.9911)$ & $+(0.8686)$ \\
\hline \multicolumn{6}{|l|}{ Subcellular localization } \\
\hline \multicolumn{6}{|l|}{ Metabolism properties } \\
\hline CYP450 2C9 Substrate & $-(0.8415)$ & $-(1.0000)$ & $-(0.7731)$ & $-(1.0000)$ & $+(0.6409)$ \\
\hline CYP450 2D6 Substrate & $-(0.7215)$ & $+(0.5870)$ & $-(0.7252)$ & $-(0.7913)$ & $-(0.7568)$ \\
\hline CYP450 3A4 Substrate & $-(0.7947)$ & $-(0.7593)$ & $+(0.5636)$ & $-(0.6488)$ & $-(0.7595)$ \\
\hline CYP450 2C9 Inhibitor & $-(0.9349)$ & $-(0.8930)$ & $-(0.5747)$ & $-(0.8930)$ & $-(0.967)$ \\
\hline CYP450 2D6 Inhibitor & $-(0.9373)$ & $-(0.7163)$ & $-(0.9203)$ & $-(0.9491)$ & $-(0.944)$ \\
\hline CYP450 2C19 Inhibitor & $-(0.9540)$ & $-(0.7723)$ & $-(0.500)$ & $-(0.8930)$ & $-(0.8805)$ \\
\hline CYP450 3A4 Inhibitor & $-(0.9877)$ & $-(0.8767)$ & $-(0.8545)$ & $-(0.9724)$ & $-(0.9463)$ \\
\hline CYP inhibitory promiscuity & $-(0.8149)$ & $-(0.9737)$ & $-(0.6444)$ & $-(0.9737)$ & $-(0.9818)$ \\
\hline \multicolumn{6}{|l|}{ Toxicity properties } \\
\hline Hepatotoxicity & $-(0.9500)$ & $-(0.7750)$ & $-(0.7500)$ & $-(0.9500)$ & $+(0.825)$ \\
\hline Acute Oral Toxicity & & II $(0.5359)$ & II $(0.8150)$ & III (0.6949) & III $(0.7484$ \\
\hline AMES (Ames mutagenesis) & & $-(0.9300)$ & $-(0.9400)$ & $-(0.5800)$ & \\
\hline
\end{tabular}

can interfere degradation process. In addition, all chemical profiles showed a positive response as oral bioavailability, water-soluble, and could bind to proteins in the blood.

\subsection{Total phenol content}

Phenolic compounds are mainly found in plants. Phenolic compounds have a protective role in human health and are beneficial in food and pharmaceutical products due to their benefits (Salar et al., 2017). The present study evaluated the quantitative estimation of phenolic compounds in BGF extract collected from North Sulawesi, Indonesia. The TPC value of BGF extract was determined by the FC method reported by Blainski et al. (2013) and Lamuela-Raventós (2017). Gallic acid was used as a standard for the calibration curve to calculate the TPC with equation $\mathrm{y}=0.0101 \mathrm{x}$ 0.0318 . The calculated result of TPC was accounted for $27539.60 \pm 35.01 \mathrm{mg} \mathrm{GAE} / 100 \mathrm{~g}$ dry extract. The results indicated that B. gymnorrhiza fruit extracts contained $a$ high level of phenolic compounds.

\subsection{Antioxidant activity analysis using the DPPH method}

The DPPH method has been widely used for antioxidant evaluation due to a stable free radical to evaluate radical scavenging activity (Liu et al., 2004). The level of discoloration exhibits the potency of antioxidants to scavenge free radicals. These phenomena due to the reaction between the 2,2-Diphenyl-1Picrylhydrazyl and antioxidant compound to form the hydrazine diphenyl picrite (Huliselan et al., 2015; Tanod et al., 2019). DPPH could reduce the exposure of radical proton scavengers (Yamaguchi et al., 1998). The antioxidants reduced the stable DPPH radicals, resulting in decreased absorbance at $517 \mathrm{~nm}$ (Behgar et al., 2011). The present study evaluated $B$. gymnorrhiza fruit extracts' antioxidant activity using the DPPH radical scavenging method with more than one concentration and compared the results with vitamin E (Figure 5).

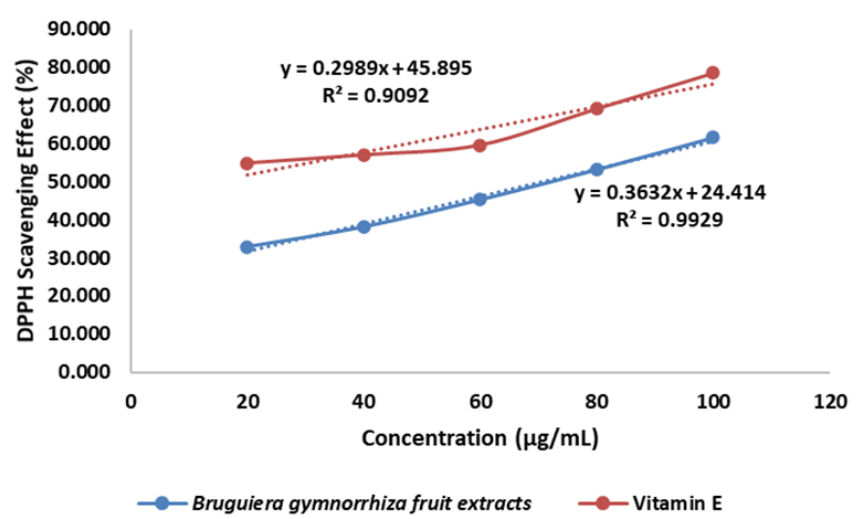

Figure 5. DPPH scavenging effect from Bruguiera gymnorrhiza mangrove fruit extracts

The B. gymnorrhiza fruit extracts were also 
evaluated for the inhibitory effect of DPPH radicals for $\mathrm{IC}_{50}$ determination (Table 3 ). The $B$. gymnorrhiza fruit extracts possessed antioxidant activity because they could donate hydrogen atoms/electrons to react with DPPH radicals. The results showed a B. gymnorrhiza fruit extracts concentration dependent on free radical scavenging and comparable with synthetic antioxidants (vitamin E). The results indicated that B. gymnorrhiza fruit extracts have strong antioxidant activity $\left(\mathrm{IC}_{50}\right.$ : $70.45 \pm 0.49 \mu \mathrm{g} / \mathrm{mL}$ ), however its activity lower than vitamin $\mathrm{E}\left(\mathrm{IC}_{50}: 13.72 \pm 1.02 \mu \mathrm{g} / \mathrm{mL}\right)$.

Table 3. $\mathrm{IC}_{50}$ of Bruguiera gymnorrhiza mangrove fruit extracts using the DPPH Radical Scavenging, compared with vitamin $\mathrm{E}$.

\begin{tabular}{lc}
\hline Mangrove fruits extract & $\mathrm{IC}_{50}(\mu \mathrm{g} / \mathrm{mL})$ \\
\hline Bruguiera gymnorrhiza & $70.45 \pm 0.49$ \\
Vitamin E & $13.72 \pm 1.02$ \\
\hline
\end{tabular}

\section{Discussion}

Bruguiera gymnorrhiza, a medicinal food plant, is widely distributed in Indonesia (Kusmana, 2014). Bruguiera gymnorrhiza has been used for several purposes, such as vegetables, firewoods (Kusmana et al., 2018), and folk medicine (Ahmed et al., 2007). The present study reported the characteristics of chemical profiles and antioxidants properties of B. gymnorrhiza fruit extracts. This study also predicted the biological activity related to antioxidant and ADMET properties of chemical profiles in B. gymnorrhiza fruit extracts. The major chemical profiles identified by GCMS from the $B$. gymnorrhiza fruit extracts were dominated by Isopimaradiene (terpenoids component) and 4-(2Aminopropyl) phenol (phenolics component) (Figure 3 and Table 1). Plant phenolics denote a major group of compounds with antioxidants properties (Adesegun et al., 2009; Pandey and Rizvi, 2009; Lin et al., 2016). Phenolics reported have the ability to strong reactive oxygen species (ROS)-scavenging activity, dropping nitrite levels, and downregulated cyclooxygenase-2 (COX-2) expression, which can play a vital role in human health (Lin et al., 2009; Rodríguez-López et al., 2020). In addition, terpenoids are also reported as antioxidant potential (Mohandas and Kumaraswamy, 2018). Terpenoids have a hydroxyl group that may act as an antioxidant due to their relatively complex cyclic structure (consisting of alcohol, aldehyde, or carboxylic acid) (Dewanto et al., 2019).

The predictive of $B$. gymnorrhiza fruit extract chemical profiles by PASS-Server of the major compounds are related to antioxidant properties. Isopimaradiene, a diterpenoid, has been reported to have anti-oxidative and anti-inflammatory properties (Kim and Kim, 2009; Tungcharoen et al., 2019) and antibacterial activity (Rijo et al., 2009). Meanwhile, 4- (2Aminopropyl) phenol is exerted antioxidant activities, free radical scavenger, $\mathrm{O}_{2}$ scavenger, and NF-E2-related factor 2 (Nrf2) stimulant. Nuclear factor erythroid 2related factor 2 (Nrf2) plays an important role in regulating the antioxidant proteins to protect against oxidative damages (Hwang and Jeong, 2010; Barajas et al., 2011; Ma, 2013; Cui et al., 2016). Under oxidative stress conditions, activated Nrf2 translocate into the nucleus and modulates antioxidant-related genes' expression at the transcriptional level (Johnson et al., 2008). Oxygen scavengers could prevent oxidation and quality foodstuff changes (Byun et al., 2011; Lalpuria et al., 2012; Mu et al., 2013). This compound has one phenol ring and one $\mathrm{NH}_{2}$ bond. $\mathrm{H}$ atoms in the phenol and $\mathrm{NH}_{2}$ ring act as electron donors to react as free radicalizers such as reactive oxygen species (ROS) (Lobo et al., 2010).

The present study has been found that $B$. gymnorrhiza fruit extracts possessed higher antioxidant potential and phytochemical content. The antioxidant potential is comparable with synthetic antioxidant vitamin E. The results revealed that $B$. gymnorrhiza fruit extracts exhibited strong antioxidant activity $\left(\mathrm{IC}_{50}\right.$ 70.45). This activity is higher than methanol extract of $B$. gymnorrhiza fruit extracts collected from the Odisha coast, India (Rout et al., 2015) and B. gymnorrhiza extract collected from Bangladesh (Hosen et al., 2020). Some factors are related to the different antioxidant activity of BG, e.g., the polarity of solvents (Jacoeb et al., 2013), the maturity of fruits (Sudirman et al., 2014), geographical locations (Rout et al., 2015; Hosen et al., 2020).

Our data showed a high level of phenolic content. This level is considerably higher than ethanol: methanol (1: 1) of B. gymnorrhiza fruit extracts $(21.9 \mathrm{mg} \mathrm{GAE} / \mathrm{g}$ powder) (Hosen et al., 2020). The extract contains 4- (2Aminopropyl) phenol and -amino-2-beunzylbutanoic acid with an aromatic ring structure with a hydroxyl group (typical of phenolic compounds).

None of the selected chemical profiles functions as $\mathrm{P}$ -glycoprotein (P-gp) substrate and inhibitors. P-gp transporter acts as a protective barrier to keep toxins out of the body and as a cellular defence system to protect the accumulation of foreign materials in the human body (Marzolini et al., 2004; Szakács et al., 2008; Quan et al., 2012; Cloos et al., 2018). After absorption in the intestine, compounds flow to the blood then metabolized in the liver. The liver CYP450 enzyme family could break down the compounds and eliminate them from the human body (Natesh et al., 2021). According to the 
ADMET analysis, 4-(2-Aminopropyl) phenol, isopimaradiene, and 3-amino-2-benzyl butanoic acid from the $B$. gymnorrhiza fruit extracts act as a substrate of CYP450 2D6, CYP450 3A4, and CYP450 2C9, respectively. Possibly, they will metabolize through those enzymes in the liver. Interestingly, all compounds are not showing any toxicity in the liver. Compound No. $1-3$ showed class II toxicity, while compounds No. 4-5 exhibited class 3 toxicity. According to the GHS United Nations 2015, the toxicity of any compounds taken orally was classified into six categories based on the $\mathrm{LD}_{50}$ ranges. Class 1 - fatal $\left(\mathrm{LD}_{50} \leq 5\right)$, class 2- fatal (5 $\left.<\mathrm{LD}_{50} \leq 50\right)$, class 3 - toxic $\left(50<\mathrm{LD}_{50} \leq 300\right)$, class 4 harmful $\left(300<\mathrm{LD}_{50} \leq 2000\right)$, class 5 - may be harmful $\left(2000<\mathrm{LD}_{50} \leq 5000\right)$, and class $6, \mathrm{LD}_{50}>5000$ is considered as non-toxic (Drwal et al., 2014).

\section{Conclusion}

It can be concluded that B. gymnorrhiza fruit extracts from Central Sulawesi could be developed as a folk medicine, nutraceutical, and functional food ingredient with antioxidant properties in a certain amount that is safe for consumption.

\section{Conflict of interest}

The authors declare no conflict of interest.

\section{Acknowledgments}

The authors would like to thank the 6th International Conference committee on Tropical and Coastal Region Eco-Development (ICTCRED) 2020, who helped in the publication process. The authors would also like to thank Siti Khalimatu Sa'diah, S.Pi., Fatma, S.Pi., and Moh. Ahdiat, S.Pi., which assists in sampling and extraction of mangrove fruit.

\section{References}

Adesegun, S.A., Fajan, A., Orabueze, C.L. and Coker, H.A.B. (2009). Evaluation of antioxidant properties of Phaulopsis fascisepala C.B.Cl. (Acanthaceae). Advanced Access Publication, 6(2), 227-231. https:// doi.org/10.1093/ecam/nem098

Acharya, S., Patra, D.K., Pradhan, C. and Mohapatra, P.K. (2020). Anti-bacterial, anti-fungal and antioxidative properties of different extracts of Bruguiera gymnorrhiza L. (Mangrove). European Journal of Integrative Medicine, 36, 101140. https:// doi.org/10.1016/j.eujim.2020.101140

Aisiah, S., Olga, Tanod, W.A., Salosso, Y., Bambang and Riyadi, P.H. (2020). Computational analysis of ethyl acetate extract of Nauclea subdita (Korth.)
Steud. leaves as peptidoglycan glycosyltransferase inhibitor in Aeromonas hydrophila. IOP Conference Series: Earth and Environmental Science, 584, 012022.

1315/584/1/012022

Al-Maqtari, M.A. and Nagi, H.M. (2014). Screening of salt-stress, antioxidant enzyme, and antimicrobial activity of leave extracts of mangroves Avicennia marina L. from Hodaidah, Yemen. Journal of Stress Physiology and Biochemistry, 10(2), 190-199.

Amin, M.N.G., Pebruwantoro, D., Pralebda, S.A., Hasan, M.N., Zakariya, Subekti, S., Pramono, H. and Alamsjah, M.A. (2021). Functional and rheological properties of mixed flour from mangrove fruit of Bruguiera gymnorrhiza flour and wheat flour. Food Research, 5(1), 167-173. https://doi.org/10.26656/ fr.2017.5(1).356

Analuddin, K., Septiana, A., Nasaruddin, Sabilu, Y. and Sharma, S. (2019). Mangrove fruit bioprospecting: nutritional and antioxidant potential as a food source for coastal communities in the Rawa Aopa Watumohai National Park, Southeast Sulawesi, Indonesia. International Journal of Fruit Science, 19 (4), 423-436. https:// doi.org/10.1080/15538362.2018.1555507

Arulkumar, A., Kumar, K.S. and Paramasivam, S. (2020). Antibacterial and invitro antioxidant potential of Indian mangroves. Biocatalysis and Agricultural Biotechnology, 23, 101491. https:// doi.org/10.1016/j.bcab.2019.101491

Armitage, D. (2020). Socio-institutional dynamics and the political ecology of mangrove forest conservation in Central Sulawesi, Indonesia. Global Environmental Change, 12(3), 203-217. https:// doi.org/10.1016/S0959-3780(02)00023-7

Barajas, B., Che, N., Yin, F., Rowshanrad, A., Orozco, L.D., Gong, K.W., Wang, X., Castellani, LW., Reue, K., Lusis, A.J. and Araujo, J.A. (2011). NF-E2 related factor 2 promotes atherosclerosis by effects on plasma lipoproteins and cholesterol transport that overshadow antioxidant protection. Arteriosclerosis, Thrombosis, and Vascular Biology, 31(1), 58-66. https://doi.org/10.1161/ATVBAHA.110.210906

Behgar, M., Ghasemi, S., Naserian, A., Borzoie, A. and Fatollahi, H. (2011). Gamma radiation effects on phenolics, antioxidants activity and in vitro digestion of pistachio (Pistachia Vera) Hull. Radiation Physics and Chemistry, 80(9), 963-967. https:// doi.org/10.1016/j.radphyschem.2011.04.016

Behbahani, E.A., Yazdi, F.T., Shahidi, F., Noorbakhsh, H., Vasiee, A. and Alghooneh, A. (2018). Phytochemical analysis and antibacterial activities extracts of mangrove leaf against the growth of some 
pathogenic bacteria. Microbial Pathogenesis, 114, 225-232.

j.micpath.2017.12.004

Blainski, A., Lopes, G.C. and De Mello, J.C.P. (2013). Application and analysis of the folin-ciocalteu method for the determination of the total phenolic content from Limonium brasiliense L. Molecules, 18 (6), 6852-6865. https://doi.org/10.3390/ molecules 18066852

Byun, Y., Darby, D., Cooksey, K., Dawson, P. and Whiteside, S. (2011). Development of oxygen scavenging system containing a natural free radical scavenger and a transition metal. Food Chemistry, 124(2), 615-619. https://doi.org/10.1016/ j.foodchem.2010.06.084

Chen, I.F, Luo, D.D., Lin, Y.S., Liu, Y.H., Wu, J.Z., Yi, X.Q., Wu, Y., Zhang, Q., Gao, C.J., Cai, J. and Su, Z.R. (2020). Aqueous extract of Bruguiera gymnorrhiza leaves protects against dextran sulfate sodium induced ulcerative colitis in mice via suppressing NF- $\mathrm{BB}$ activation and modulating intestinal microbiota. Journal of Ethnopharmacology, 251, 112554. https:// doi.org/10.1016/j.jep.2020.112554

Clarke, G., Ting, K.N., Wiart, C. and Fry, J. (2013). High correlation of 145 2,2-Diphenyl-1Picrylhydrazyl (DPPH) radical scavenging, ferric reducing activity potential and total phenolics content indicates redundancy in use of all three assays to screen for antioxidant activity of extracts of plants from the Malaysian rainforest. Antioxidants, 2 (1), 1-10. https://doi.org/10.3390/antiox2010001

Cloos, J., Jansen, G., Jaramillo, A.C., Saig, F.A. and Peters, G.J. (2018). How to overcome ATP-binding cassette drug efflux transporter-ediated drug resistance?. Cancer Drug Resistance, 1(1), 6-29. https://doi.org/10.20517/cdr.2018.02

Cui, T., Lai, Y., Janicki, J.S. and Wang, X. (2016). Nuclear factor erythroid-2 related factor 2 (Nrf2)mediated protein quality control in cardiomyocytes. Frontiers in Bioscience, 21, 192-202. https:// doi.org/10.2741/4384

Dahdouh-Guebas, F., Mathenge, C., Kairo, J.G. and Koedam, N. (2000). Utilization of mangrove wood products around mida creek (Kenya) amongst subsistence and commercial users. Economic Botany, 54(4), 513-527. https://doi.org/10.1007/ BF02866549

Damanik, R. and Djamaludin, R. (2012). Atlas Mangrove Teluk Tomini. Makassar, Indonesia: SUSCLAM Sustainable Coastal Livelihoods and Management Program.
Dewanto, D.K., Finarti, F., Hermawan, R., Ndobe, S., Riyadi, P.H. and Tanod, W.A. (2019). Antioxidant Activity of Soft Corals Extracts from Palu Bay, Central Sulawesi, Indonesia. Jurnal Pascapanen Dan Bioteknologi Kelautan Dan Perikanan, 14(2), 163-178. https://doi.org/10.15578/jpbkp.v14i2.583

Dewanto, D.K., Tanod, W.A., Finarti, F. and Renol, R. (2018). Screening of Antiradical Activity From Some Central Sulawesi Mangroves. Pharmaciana, 8 (1), 155-168. https://doi.org/10.12928/ pharmaciana.v8i1.8187

Dong, J., Wang, N.N., Yao, Z.J., Zhang, L., Cheng, Y., Ouyang, D., Lu, A.P. and Cao, D.S. (2018). ADMETlab: a platform for systematic ADMET evaluation based on a comprehensively collected ADMET database. Journal of Cheminformatic, 10 (29), 1-11. https://doi.org/10.1186/s13321-018-0283 $-\mathrm{X}$

Drwal, M.N., Banerjee, P., Dunkel, M., Wettig, M.R. and Preissner, R. (2014). ProTox: a web server for the in silico prediction of rodent oral toxicity. Nucleic Acids Research, 42(W1), W53W58. https://doi.org/10.1093/nar/gku401

Eswaraiah, G., Peele, K. A., Krupanidhi, S., Kumar, R.B. and Venkateswarulu, T.C. (2020). Studies on phytochemical, antioxidant, antimicrobial analysis and separation of bioactive leads of leaf extract from the selected mangroves. Journal of King Saud University - Science, 32(1), 842-847. https:// doi.org/10.1016/j.jksus.2019.03.002

Guan, L., Yang, H., Cai, Y., Sun, L., Di, P., Li, W., Liu, G. and Tang, Y. (2019). ADMET-score - a comprehensive scoring function for evaluation of chemical drug-likeness. Medicine Chemical Communication, 10(1), 148-157. https:// doi.org/10.1039/C8MD00472B

Filimonov, D. and Poroikov, V. (2008). Probabilistic Approaches in Activity Prediction. In Varnek, A. and Tropsha, A. (Eds.). Chemoinformatics Approaches to Virtual Screening, p. 182-216. Cambridge: RSC Publishing. https:// doi.org/10.1039/9781847558879-00182

Hosen, M.Z., Biswas, A., Islam, M.R., Bhuiyan, M.N.I. and Hossain, S.J. (2020). Comparison of physicochemical and antioxidant properties of edible fruits in the sundarbans' mangrove forest, Bangladesh. Bangladesh Journal of Botany, 49(3), 671-678. https://doi.org/10.3329/bjb.v49i3.50009

Hsiao, T.H., Sung, C.S., Lan, Y.H., Wang, Y.C., Lu, M.C., Wen, Z.H., Wu, Y.C. and Sung, P.J. (2015). New anti-inflammatory cembranes from the cultured soft coral Nephthea columnaris. Marine Drugs, 13 (6), 3443-3453. https://doi.org/10.3390/ 
md13063443

Huliselan, Y.M., Runtuwene, M.R.J. and Wewengkang, D.S. (2015). Antioxidant activity of ethanol, ethyl acetate and n-hexane extract from seswanua leaves (Clerodendron squamatum Vahl.). Pharmacon, 4(3), 155-163. https://doi.org/10.1016/j.taap.2009.09.009

Hwang, Y.P. and Jeong, H.G. (2010). Ginsenoside Rb1 protects against 6-hydroxydopamine-induced oxidative stress by increasing heme oxygenase-1 expression through an estrogen receptor-related $\mathrm{PI} 3 \mathrm{~K} / \mathrm{Akt} / \mathrm{Nrf2}$-dependent pathway in human dopaminergic cells. Toxicology and Applied Pharmacology, 242(1), 18-28.

Jacoeb, A.M., Suptijah, P. and Zahidah. (2013). Chemical composition, bioactive component and antioxidant activity of large-leafed mangrove (Bruguiera gymnorrhiza) fruit. Jurnal Pengolahan Hasil Perikanan Indonesia, 16(1), 86-94.

Jariyah, Widjanarko, S.B., Yunianta, Estiasih, T. and Sopade, P.A. (2014). Pasting properties mixtures of mangrove fruit flour (Sonneratia caseolaris) and starches. International Food Research Journal, 21 (6), 2161-2167.

Johnson, J.A., Johnson, D.A., Kraft, A.D., Calkins, M.J., Jakel, R.J., Vargas, M.R. and Chen, P. (2008). The Nrf2-ARE pathway an indicator and modulator of oxidative stress in neurodegeneration. Annals of the New York Academy of Sciences, 1147(1), 61-69. https://doi.org/10.1196/annals.1427.036

Karim, M.A., Islam, M.A., Islam, M.M., Rahman, M.S., Sultana, S., Biswas, S., Hosen, M.J., Mazumder, K., Rahman, M.M. and Hasan, M.N. (2020). Evaluation of antioxidant, anti-hemolytic, cytotoxic effects and anti-bacterial activity of selected mangrove plants (Bruguiera gymnorrhiza and Heritiera littoralis) in Bangladesh. Clinical Phytoscience, 6(8), 1-12. https://doi.org/10.1186/s40816-020-00162-3

Kardiman, Ridhwan, M. and Armi. (2017). Lindur fruit (Bruguiera gymnorrhiza) as food for the Acehnese archipelago. Serambi Saintia, 5(2), 51-55.

Kim, J. and Kim, S. (2009). Anti-inflammatory activities of Illicium anisatum essential oil. Acta Pharmaceutica, 59, 289-300. https:// doi.org/10.2478/v10007-009-0022-y

Kusmana, C. (2014). Distribution and Current Status of Mangrove Forests in Indonesia. In Faridah-Hanum, I., Latiff, A., Hakeem, K.R., Özturk, M. (Eds). Mangrove Ecosystems of Asia: Status, Challenges and Management Strategies, p. 37-60. New York: Springer-Verlag. https://doi.org/10.1007/978-1-4614 $-8582-73$

Kusmana, C., Hidayat, T., Istomo and Rusdiana, O.
(2018). Growth performance of Bruguiera gymnorrhiza deriver from cut-propagule seedling. Biodiversitas, 19(1), 208-214. https:// doi.org/10.13057/biodiv/d190128

Lalpuria, M., Anantheswaran, R. and Floros, J. (2012). Packaging technologies and their role in food safety. In Demirci, A. and Ngadi, M.O. (Eds). Microbial decontamination in the food industry: Novel methods and applications, p. 701-745. Cambridge, United Kingdom: Woodhead Publishing Limited. https://doi.org/10.1533/9780857095756.4.701

Lamuela-Raventós, R.M. (2017). Folin-Ciocalteu method for the measurement of total phenolic content and antioxidant capacity. In Apak, R., Capanoglu, E. and Shahidi, F. (Eds). Measurement of Antioxidant Activity and Capacity: Recent Trends and Applications, p. 107-115. New Jersey, USA: John Wiley and Sons Ltd. https:// doi.org/10.1002/9781119135388.ch6

Lin, Y., Zheng, X., Chen, J., Luo, D., Xie, J., Su, Z., Huang, X., Yi, X., Wei, L., Cai, J. and Sun, Z. (2020) Protective Effect of Bruguiera gymnorrhiza (L.) Lam. Fruit on Dextran Sulfate Sodium-Induced Ulcerative Colitis in Mice: Role of Keap1/Nrf2 Pathway and Gut Microbiota. Frontier Pharmacology, 10, 1602. https://doi.org/10.3389/ fphar.2019.01602

Lisna, M.A. and Toknok, B. (2017). Potential of mangrove forest vegetation in the coastal area of the equatorial village, Tinombo Selatan sub-district, Parigi Moutong district. Warta Rimba, 5(1), 63-70.

Li, Q., Nengwang, Y., Yanping, W., Yanping, S., Kangping, L. and Wenling, G. (2013). Extraction optimization of Bruguiera gymnorrhiza polysaccharides with radical scavenging activities. Carbohydrate Polymers, 96(1), 148-155. https:// doi.org/10.1016/j.carbpol.2013.03.054

Liu, J.K., Lin, H., Dong, Z.J. and Hu, Q. (2004). DPPH radical scavenging activity of ten natural $\mathrm{p}$-terphenyl derivatives obtained from three edible mushrooms indigenous to China. Chemistry and Biodiversity, 1 (4), 601-605. https://doi.org/10.1002/ cbdv. 200490050

Lobo, V., Patil, A., Phatak, A. and Chandra, N. (2010). Free radicals, antioxidants and functional foods: Impact on human health. Pharmacognosy Reviews, 4 (8), 118-126. https://doi.org/10.4103/09737847.70902

Ma, Q. (2013). Role of Nrf2 in oxidative stress and toxicity. Annual Review of Pharmacology and Toxicology, 53, 401-426. https://doi.org/10.1146/ annurev-pharmtox-011112-140320 
Marzolini, C., Paus, E., Buclin, T. and Kim, R.B. (2004). Polymorphisms in human MDR1 (P-glycoprotein): recent advances and clinical relevance. Clinical Pharmacology and Therapeutics, 75(1), 13-33. https://doi.org/10.1016/j.clpt.2003.09.012

Mohandas, G.G. and Kumaraswamy, M. (2018). Antioxidant Activities of Terpenoids from Thuidium tamariscellum (C. Muell.) Bosch. and Sande-Lac. a Moss. Pharmacognition Journal, 10(4), 645-649. https://doi.org/10.5530/pj.2018.4.106

Molyneux, P. (2004). The use of the stable free radical diphenylpicryl-hydrazyl (DPPH) for estimating antioxidant activity. Songklanakarin Journal of Science and Technology, 26(2), 211-219.

$\mathrm{Mu}, \mathrm{H} .$, Gao, H., Chen, H., Tao, F., Fang, X. and Ge, L. (2013). A nanosised oxygen scavenger: preparation and antioxidant application to roasted sunflower seeds and walnuts. Food Chemistry, 136(1), 245250. https://doi.org/10.1016/j.foodchem.2012.07.121

Natesh, J., Mondal, P., Penta, D., Salam, A.A.A. and Meeran, S.M. (2021). Culinary spice bioactives as potential therapeutics against SARS-CoV-2: Computational investigation. Computers in Biology and Medicine, 128, 104102. https://doi.org/10.1016/ j.compbiomed.2020.104102

Noor, Y.R., Khazali, M. and Suryadiputra, I.N. (2006). Panduan Pengenalam Mangrove di Indonesia. $2^{\text {nd }} \mathrm{ed}$. Bogor: Wetlands International Indonesia Programme.

Pandey, K.B. and Rizvi, S.I. (2009). Plant Polyphenols as Dietary Antioxidants in Human Health and Disease. Oxidative Medicine and Cellular Longevity, 2(5), 270-278. https://doi.org/10.4161/ oxim.2.5.9498

Putra, M.Y., Murniasih, T., Swasono, R.T., Wibowo, J.T., Saputri, A.N.C., Widhiana, M.R. and Arlyza, I.S. (2016). Secondary metabolites and their biological activities in Indonesian soft coral of the genus Lobophytum. Asian Pacific Journal of Tropical Biomedicine, 6(11), 909-913. https:// doi.org/10.1016/j.apjtb.2016.08.011

Quan, Y., Jin, Y., Faria, T.N., Tilford, C.A., He, A., Wall, D.A., Smith, R.L. and Vig, B.S. (2012). Expression profile of drug and nutrient absorption related genes in madin-darby canine kidney (MDCK) cells grown under differentiation conditions. Pharmaceutics, 4(2), 314-333. https:// doi.org/10.3390/pharmaceutics4020314

Riyadi, P.H., Romadhon R., Anggo A.D., Herawati V.E. and Setyastuti A.I. (2020) PASS and ADMET analyses for eight compounds from Nile tilapia (Oreochromis niloticus) viscera waste hydrolysate as anti-inflammatory nutraceutical. AACL Bioflux, 13
(5), 2630-2638.

Riyadi, P.H., Tanod, W.A., Wahyudi, D., Susanto, E., Fahmi, A.S. and Aisiah, S. (2020). Potential of tilapia (Oreochromis niloticus) viscera bioactive peptides as antiviral for SARS-CoV-2 (COVID 19). IOP Conference Series: Earth and Environmental Science, 584, 012004. https://doi.org/10.1088/17551315/584/1/012004

Rodríguez-López, P., Lozano-Sanchez, J., BorrásLinares, I., Emanuelli, T.; Menéndez, J.A. and Segura-Carretero, A. (2020). Structure-Biological Activity Relationships of Extra-Virgin Olive Oil Phenolic Compounds: Health Properties and Bioavailability. Antioxidants, 9(8), 685-702. https:// doi.org/10.3390/antiox9080685

Rout, P. and Basak, U.C. (2014). Antioxidant properties in leaf and root extracts of some medicinally important mangrove species of Odisha Coast. American Journal of Pharmtech Research, 4(4), 605 -617 .

Rout, P., Singh, S., Kumar, N. and Basak, U.C. (2015). Nutritional and antioxidant potential of some selected edible mangrove fruits of Odisha coast. International Journal of Advances in Scientific Research, 1(9), 349-355. https://doi.org/10.7439/ ijasr.v1i9.2624

Rijo, P., Simões, M.F., Duarte, A. and Rodríguez, B. (2009). Isopimarane diterpenoids from Aeollanthus rydingianus and their antimicrobial activity. Phytochemistry, 70(9), 1161-1165. https:// doi.org/10.1016/j.phytochem.2009.06.008

Szakács, G., Váradi, A., Özvegy-Laczka, C. and Sarkadi, B. (2008). The role of abc transporters in drug absorption, distribution, metabolism, excretion and toxicity (ADME-Tox). Drug Discovery Today 13(910), 379-393. https://doi.org/10.1016/ j.drudis.2007.12.010

Situmorang, R.O.P. and Barus, S.P. (2015). Mangrove management as source of food alternative by the women fishermen group in Sei Nagalawan, North Sumatra, Indonesia, presented at International Conference of Indonesia Forestry Researchers III, Bogor, 2015. Indonesia, Ministry of Environment and Forestry-Research, Development and Innovation Agency.

Sudirman, S., Nurjanah and Jacoeb, A.M. (2014). Proximate compositions, bioactive compounds and antioxidant activity from large-leafed mangrove (Bruguiera gymnorrhiza) fruit. International Food Research Journal, 21(6), 2387-2391.

Suh, S.S., Hwang, J., Park, M., Park, H.S. and Lee, T.K. (2014). Phenol content, antioxidant and tyrosinase inhibitory activity of mangrove plants in Micronesia. 
Asian Pacific Journal of Tropical Medicine, 7(7),

531-535. https://doi.org/10.1016/S1995-7645(14)

60089-4

Tanod, W.A., Dewanto, D.K., Ndobe, S., Riyadi, P.H., and Putra, M.Y. (2019). Screening of antibacterial and antioxidant activity of soft corals Sinularia sp. and Sarcophyton sp. from Palu Bay Central Sulawesi. Squalen: Bulletin of Marine and Fisheries Postharvest and Biotechnology, 14(2), 73-83. https://doi.org/10.15578/squalen.v14i2.394

Tanod, W.A., Yanuhar, U., Maftuch, Wahyudi, D. and Risjani, Y. (2019). DPPH scavenging property of bioactives from soft corals origin palu bay, Central Sulawesi, Indonesia. IOP Conference Series: Earth and Environmental Science, 236, 012121. https:// doi.org/10.1088/1755-1315/236/1/012121

Tungcharoen, P., Wattanapiromsakul, C., Tansakul, P., Nakamura, S., Matsuda, H. and Tewtrakul, S. (2019). Anti-inflammatory effect of isopimarane diterpenoids from Kaempferia galanga. Phytotherapy Research, 34(3), 612-623. https:// doi.org/10.1002/ptr.6549

Van de Waterbeemd, H. and Gifford, E. (2003). ADMET in silico modelling: towards prediction paradise?. Nature Reviews Drug Discovery, 2(3), 192-204. https://doi.org/10.1038/nrd1032

Wibawanti, J.M.W., Fadhiliya, L., Pamungkas, S. and Mudawaroch, R.E. (2018). Mangrove Processed Alternative Functional Food Production in Purworejo Regency. Community Empowerment, 3 (1), 27-33. https://doi.org/10.31603/ce.v3i1.2450

Yamaguchi, T., Takamura, H., Matoba, T. and Terao, J. (1998). HPLC method for evaluation of the free radical-scavenging activity of foods by using 1, 1diphenyl-2-picrylhydrazyl. Bioscience Biotechnology Biochemistry, 62(6), 1201-1204. https:// doi.org/10.1271/bbb.62.1201

Yu, L., Haley, S., Perret, J., Harris, M., Wilson, J. and Qiant, M. (2002). Free radical scavenging properties of wheat extracts. Journal of Agricultural and Food Chemistry, 50(6), 1619-1624. https:// doi.org/10.1021/jf010964p

Zhu, Z., Chen, J., and Zheng, H.-L. (2012). Physiological and proteomic characterization of salt tolerance in a mangrove plant, Bruguiera gymnorrhiza (L.) Lam. Tree Physiology, 32(11), 1378-1388. https:// doi.org/10.1093/treephys/tps097 